\title{
Integrated Method for the Measurement of Trace Atmospheric Bases
}

Daryl Key, Jerome Stihle, Jean-Eudes Petit, Cécile Bonnet, Lauriane Depernon, Oscar Liu, Sean Kennedy, Robyn Latimer, Marnie Burgoyne, Darcy Wanger, Alexandre Webster, Samantha Casunuran, Sergio Hidalgo, Mark Thomas, John A. Moss, and Marc M. Baum*

Oak Crest Institute of Science, Pasadena, California

Supplementary Material

Table of Contents

General S2

High Performance Liquid Chromatography Conditions S3

Gas Chromatography Conditions

S3-4

Preparation of Authentic Samples S4-6

Denuder Efficiency Tests

S6

Impinger Efficiency Tests

S6-7

Tables

Figures

References

S12 


\section{S.1 Experimental}

\section{S.1.1 General}

Chemicals and reagents were of analytical reagent grade, or equivalent, and were purchased from Acros Organics (Morris Plains, NJ), Alfa Aesar (Ward Hill, MA), Sigma-Aldrich (Milwaukee, WI), and Spectrum Chemical (Gardena, CA) and used as received unless described below. Sodium nitroprusside was stored in a desiccator and used within six months of purchase. 2Furaldehyde was distilled over anhydrous potassium carbonate $(5 \% \mathrm{w} / \mathrm{w})$ under argon and was stored in the dark, under argon, at $-80^{\circ} \mathrm{C}$. All other solvents and reagents were purified when necessary using standard procedures. The following nitrogenous bases were used: ammonium chloride (Alfa Aesar), methylamine hydrochloride (Aldrich), dimethylamine hydrochloride (Acros Organics), ethylamine $(70 \%$ in water, Spectrum Chemical), diethylamine (Acros Organics), ethylmethylamine (Acros Organics), morpholine (Spectrum Chemical), aniline (Aldrich), hydrazine dihydrochloride (Acros Organics), methylhydrazine (Acros Organics), hydroxylamine hydrochloride (Aldrich). Methylhydrazine sulfate was prepared from methylhydrazine and sulfuric acid in methanol. Working standard solutions were prepared by serially diluting stock solutions with $0.04 \% \mathrm{w} / \mathrm{v}$ phosphorous acid in deionized water $\left(D I-\mathrm{H}_{2} \mathrm{O}\right)$.

The chromatography instrumentation used in this project consisted of the following. High performance liquid chromatography with mass spectrometric detection was carried out on an Agilent1100 LC system interfaced to an Agilent 1100 mass selective detector operating in electrospray ionization (ESI) mode Gas chromatography with mass spectrometric detection (GC/MS) was carried out either on a 5890 Series II gas chromatograph (Hewlett Packard) coupled to a 5972 mass selective detector (Hewlett-Packard) or on a 7890A GC System (Agilent Technologies) coupled to a 5975C Inert XL EI/CI mass selective detector (Agilent Technologies). Another 5890 Series II GC was used with a flame ionization detector (FID) and a nitrogen phosphorous detector (NPD).

${ }^{1} \mathrm{H}$ Nuclear Magnetic Resonance spectra were acquired at $300 \mathrm{MHz}$ on a Model Mercury-Vx 300 (Varian) and processed using NUTS software (Acorn NMR). All spectra in $\mathrm{CDCl}_{3}$ are referenced to the solvent singlet at $7.26 \mathrm{ppm}$. The abbreviations s, d, t, $\mathrm{q}$, and $\mathrm{m}$ stand for singlet, doublet, 
triplet, quartet, and multiplet, respectively. Melting points were obtained using a Mel-Temp (Barnstead International, Dubuque, IA) electrothermal unit and are uncorrected.

Liquid chromatography conditions.

\section{S.1.2 High performance liquid chromatography conditions}

HPLC conditions for all measurements are provided below.

Amines: column, Kinetex C8 100A (Phenomenex); column dimensions: $2.1 \times 100 \mathrm{~mm}, 2.6 \mu \mathrm{m}$ particle size $\left(28^{\circ} \mathrm{C}\right)$; injection volume, $100 \mu \mathrm{L}$; flow rate, $200 \mu \mathrm{L} \mathrm{min}^{-1}$; isocratic, $50: 50 \mathrm{~A}: \mathrm{B}(\mathrm{A}$, $20 \mathrm{mM}$ ammonium acetate; B, methanol); diode array detector, $354 \mathrm{~nm}$; MS nebulizer pressure, $35 \mathrm{psig}$; fragmenter, $135 \mathrm{~V}$; single ion mode (choice of ions depends on the experiment). Seven standards consisting of seven derivatized amines were run at the front and back end of the run.

Activated primary amines $\left(\mathrm{X}-\mathrm{NH}_{2}\right)$ : column, Kinetex C8 100A (Phenomenex); column dimensions: $2.1 \times 100 \mathrm{~mm}, 2.6 \mu \mathrm{m}$ particle size $\left(28^{\circ} \mathrm{C}\right)$; injection volume, $100 \mu \mathrm{L}$; flow rate, 400 $\mu \mathrm{L}$ min $^{-1}$; gradient program, 2 min hold 95:5 A:B (A, $10 \mathrm{mM}$ ammonium formate, $\mathrm{pH} 3$; $\mathrm{B}$, acetonitrile), $5 \mathrm{~min}$ ramp to $10: 90 \mathrm{~A}: \mathrm{B} ; 1$ min hold at 10:90 A:B; diode array detector, $266 \mathrm{~nm}$; MS nebulizer pressure, $60 \mathrm{psig}$; fragmenter, $114 \mathrm{~V}$; single ion mode (choice of ions depends on the experiment). Seven standards consisting of three derivatized activated primary amines were run at the front and back end of the run.

\section{S.1.3 Gas chromatography conditions}

GC conditions for all measurements are provided below.

Amines: column, DB-5 MS (Agilent); column dimensions, L, $30 \mathrm{~m}, \mathrm{ID}, 0.25 \mathrm{~mm}, \mathrm{DF}, 0.5 \mu \mathrm{m}$; injection volume, $2 \mu \mathrm{L}$; injector temperature, $265^{\circ} \mathrm{C}$; injection mode, pulsed-splitless; injection pulse pressure, 25 psi until $0.55 \mathrm{~min}$; purge flow to split vent, $100 \mathrm{~mL} \mathrm{~min}^{-1}$ at $0.55 \mathrm{~min}$; temperature profile, $80^{\circ} \mathrm{C}$ for $3 \mathrm{~min}, 35^{\circ} \mathrm{C} \mathrm{min}^{-1}$ to $275^{\circ} \mathrm{C}$, hold at $275^{\circ} \mathrm{C}$ for $7 \mathrm{~min}$; detector temperature, $275^{\circ} \mathrm{C}$; carrier gas, helium; carrier gas flow rate, $1.23 \mathrm{~mL} \mathrm{~min}^{-1}$; internal standard, 1-fluoronaphthalene. The following conditions were used for analysis by GC/NPD: column, DB$5 \mathrm{MS}$ (Agilent); column dimensions, L, $30 \mathrm{~m}, \mathrm{ID}, 0.32 \mathrm{~mm}, 0.5 \mu \mathrm{m}$ film; injection volume, $2 \mu \mathrm{L}$; injector temperature, $225^{\circ} \mathrm{C}$; injection mode, pulsed-splitless; purge flow to split vent, $100 \mathrm{~mL}$ 
$\min ^{-1}$ at $0.45 \mathrm{~min}$; temperature profile, temperature profile, $80^{\circ} \mathrm{C}$ for $3 \mathrm{~min}, 35^{\circ} \mathrm{C} \mathrm{min}^{-1}$ to $275^{\circ} \mathrm{C}$, hold at $275^{\circ} \mathrm{C}$ for $7 \mathrm{~min}$; detector temperature, $250^{\circ} \mathrm{C}$; carrier gas, helium; carrier gas flow rate (constant flow mode), $1.75 \mathrm{~mL} \mathrm{~min}^{-1}$; internal standard, 4-nitrophenyl acetate.

Activated primary amines $\left(\mathrm{X}-\mathrm{NH}_{2}\right)$ : The following conditions were used for analysis by GC/MS: column, DB-5 MS (Agilent); column dimensions, L, $30 \mathrm{~m}, \mathrm{ID}, 0.25 \mathrm{~mm}, \mathrm{DF}, 0.5 \mu \mathrm{m}$; injection volume, $2 \mu \mathrm{L}$; injector temperature, $200^{\circ} \mathrm{C}$; injection mode, pulsed-splitless; injection pulse pressure, 25 psi until $0.55 \mathrm{~min}$; purge flow to split vent, $100 \mathrm{~mL} \mathrm{~min}^{-1}$ at $0.35 \mathrm{~min}$; temperature profile, $65^{\circ} \mathrm{C}$ for $3 \mathrm{~min}, 35^{\circ} \mathrm{C} \min ^{-1}$ to $175^{\circ} \mathrm{C}$, hold at $175^{\circ} \mathrm{C}$ for $7 \mathrm{~min}, 20^{\circ} \mathrm{C}$ to $250^{\circ} \mathrm{C}$; detector temperature, $275^{\circ} \mathrm{C}$; carrier gas, helium; carrier gas flow rate, $1.23 \mathrm{~mL} \mathrm{~min}^{-1}$; internal standard, 1-fluoronaphthalene. The following conditions were used for analysis by GC/NPD: column, DB$5 \mathrm{MS}$ (Agilent); column dimensions, L, $30 \mathrm{~m}$, ID, $0.32 \mathrm{~mm}, 0.5 \mu \mathrm{m}$ film; injection volume, $2 \mu \mathrm{L}$; injector temperature, $225^{\circ} \mathrm{C}$; injection mode, pulsed-splitless; purge flow to split vent, $100 \mathrm{~mL}$ $\min ^{-1}$ at $0.45 \mathrm{~min}$; temperature profile, temperature profile, $65^{\circ} \mathrm{C}$ for $3 \mathrm{~min}, 35^{\circ} \mathrm{C} \mathrm{min}^{-1}$ to $175^{\circ} \mathrm{C}$, hold at $175^{\circ} \mathrm{C}$ for $7 \mathrm{~min}, 20^{\circ} \mathrm{C}$ to $250^{\circ} \mathrm{C}$; detector temperature, $250^{\circ} \mathrm{C}$; carrier gas, helium; carrier gas flow rate (constant flow mode), $1.75 \mathrm{~mL} \mathrm{~min}^{-1}$; internal standard, 4-nitrophenyl acetate.

\section{S.1.4 Preparation of authentic samples}

The method described by Day et al. (Day et al., 1966), modified as described below, was used to prepare authentic samples. The amine or amine salt $(1.0 \mathrm{~g})$ was dissolved in borate buffer (50 $\mathrm{mL})$ consisting of aqueous sodium tetraborate decahydrate $(2.5 \% \mathrm{w} / \mathrm{v})$. 2,4-Dinitrofluorobenzene (DNFB, $2 \mathrm{~mL}$ in $25 \mathrm{~mL}$-dioxane) was added and the mixture was heated at $100{ }^{\circ} \mathrm{C}$ for $1 \mathrm{~h}$ using an air condenser. Aqueous sodium hydroxide solution $(1 \mathrm{M}, 50 \mathrm{~mL})$ and added to the cooled solution and the resulting mixture was heated at $100{ }^{\circ} \mathrm{C}$ for $1 \mathrm{~h}$ to hydrolyze excess reagent. After cooling, the solid was filtered, washed with $0.1 \mathrm{~N}$ sodium carbonate solution and recrystallized. When a solid did not precipitate from the reaction mixture, it was extracted using an appropriate organic solvent. All products were found to be pure by GC/MS and by ${ }^{1} \mathrm{H}$ NMR spectroscopy.

N-Methyl-2,4-dinitronaniline: orange crystals (1.44 g, 49\%) recrystallized from acetone; mp 176.5-178 $\mathrm{C}$, Lit. $178-180^{\circ} \mathrm{C}$ (Hollingsworth, 1959); ${ }^{1} \mathrm{H}$ NMR $\left(300 \mathrm{MHz}, \mathrm{CDCl}_{3}\right) \delta 3.15$ (s, 3H), 6.93 (d, $9.5 \mathrm{~Hz}, 1 \mathrm{H}), 8.29$ (dd, $9.5 \& 2.3 \mathrm{~Hz}, 1 \mathrm{H}), 8.59$ (s br, 1H), 9.14 (d, $2.6 \mathrm{~Hz}, 1 \mathrm{H})$. 
N,N-Diethyl-2,4-dinitronaniline: extract with hexane; orange crystals $(2.07 \mathrm{~g}, 63 \%)$ precipitate from hexane extracts; mp $83-84^{\circ} \mathrm{C}$, Lit. $67-68^{\circ} \mathrm{C}$ (Day et al., 1966); ${ }^{1} \mathrm{H} \mathrm{NMR}\left(300 \mathrm{MHz}, \mathrm{CDCl}_{3}\right.$ ) $\delta 1.23(\mathrm{t}, 7.1 \mathrm{~Hz}, 6 \mathrm{H}), 3.35(\mathrm{q}, 7.0 \mathrm{~Hz}, 4 \mathrm{H}), 7.05(\mathrm{~d}, 9.5 \mathrm{~Hz}, 1 \mathrm{H})$.

N-Phenyl-2,4-dinitronaniline: extract with hexane; orange crystals $(2.86 \mathrm{~g}, 100 \%)$ precipitate from hexane extracts; mp $154-155^{\circ} \mathrm{C}$, Lit. $153-155^{\circ} \mathrm{C}$ (Elder and Holtz, 1996); ${ }^{1} \mathrm{H}$ NMR (300 $\left.\mathrm{MHz}, \mathrm{CDCl}_{3}\right) \delta 7.35(\mathrm{~m}, 6 \mathrm{H}), 8.18(\mathrm{ddd}, 9.5,2.7, \& 0.7 \mathrm{~Hz}, 1 \mathrm{H}), 9.19(\mathrm{~d}, 2.7 \mathrm{~Hz}, 1 \mathrm{H}), 9.99(\mathrm{~s} b r$, $1 \mathrm{H})$.

2-Furaldehyde azine: To freshly distilled 2-furaldehyde (1.92 g, $20 \mathrm{mmol})$ in a three-necked round bottom flask was added reagent alcohol $(10 \mathrm{~mL})$, followed by concentrated sulfuric acid (4 drops). Anhydrous hydrazine ( 0.5 equiv., $10 \mathrm{mmol}, 0.32 \mathrm{~g}, 0.32 \mathrm{~mL}$ ) dissolved in reagent alcohol $(5 \mathrm{~mL})$ was added dropwise to the aldehyde solution via a pressure-equalized dropping funnel. The mixture was stirred for $2 \mathrm{~h}$ under reflux, cooled to room temperature, and the resulting solid filtered in vacuo using a Buchner funnel. The solid was recrystallized from reagent alcohol; mp $104{ }^{\circ} \mathrm{C} ;{ }^{1} \mathrm{H}$ NMR $\left(300 \mathrm{MHz}, \mathrm{CDCl}_{3}\right) \delta 6.54(\mathrm{q}, \mathrm{J}=2 \mathrm{~Hz}, 1 \mathrm{H}) 6.90(\mathrm{dd}, \mathrm{J}=3 \mathrm{~Hz}, 1 \mathrm{~Hz}, 1 \mathrm{H}) 7.60$ $(\mathrm{d}, \mathrm{J}=1 \mathrm{~Hz}, 1 \mathrm{H}) 8.51(\mathrm{~s}, 1 \mathrm{H})$.

2-Furaldehyde-N-methylhydrazone: To freshly distilled 2-furaldehyde $(1.92 \mathrm{~g}, 20 \mathrm{mmol})$ in a three-necked round bottom flask was added reagent alcohol $(10 \mathrm{~mL})$, followed by concentrated sulfuric acid (4 drops). Methylhydrazine (1 equiv., $20 \mathrm{mmol}, 0.92 \mathrm{~g}, 1.06 \mathrm{~g}$ ) dissolved in reagent alcohol $(5 \mathrm{~mL})$ was added dropwise to the aldehyde solution via a pressure-equalized dropping funnel. The mixture was stirred for $2 \mathrm{~h}$ at reflux, cooled to room temperature, and the solvent evaporated in vacuo. The resulting brown oil was distilled under reduced pressure to afford the title compound as a colorless oil that was stored under argon at $-30{ }^{\circ} \mathrm{C} ;{ }^{1} \mathrm{H}$ NMR $(300 \mathrm{MHz}$, $\left.\mathrm{CDCl}_{3}\right) \delta 2.80(\mathrm{~s}, 3 \mathrm{H}) 6.30(\mathrm{~m}, 2 \mathrm{H}) 7.30(\mathrm{~m}, 2 \mathrm{H})$.

2-Furaldehyde oxime: To freshly distilled 2-furaldehyde (1.92 g, $20 \mathrm{mmol})$ in a three-necked round bottom flask was added reagent alcohol $(10 \mathrm{~mL})$, followed by concentrated sulfuric acid (4 drops). Hydroxylamine hydrochloride (1 equiv., $20 \mathrm{mmol}, 1.39 \mathrm{~g}$ ) was neutralized with $2 \mathrm{~N}$ sodium hydroxide solution $(10 \mathrm{~mL})$ and was added dropwise to the aldehyde solution via a pressure-equalized dropping funnel. The mixture is stirred for $2 \mathrm{~h}$ at reflux, cooled to room temperature, and the resulting solid filtered in vacuo using a Buchner funnel. The solid was 
recrystallized from reagent alcohol; $\mathrm{mp} 89-90^{\circ} \mathrm{C} ;{ }^{1} \mathrm{H} \mathrm{NMR}\left(300 \mathrm{MHz}, \mathrm{CDCl}_{3}\right) \delta 6.50(\mathrm{tm}, 1 \mathrm{H})$ $7.35(\mathrm{~d}, 1 \mathrm{H}) 7.51(\mathrm{~m}, 1 \mathrm{H}) 8.00(\mathrm{~s}, 1 \mathrm{H})$.

\section{S.1.5 Denuder efficiency tests}

Acid-coated denuders (URG-2000-30B, URG) were prepared as follows. Phosphorous acid (5 g) was heat-treated in an oven at $120^{\circ} \mathrm{C}$ over night to remove volatile trace impurities and was cooled to room temperature in a desiccator. HPLC-grade methanol was distilled over sulfuric acid $(1 \%, \mathrm{v} / \mathrm{v})$ to remove traces of amines. A $1 \% \mathrm{w} / \mathrm{v}$ solution of the purified phosphorous acid in distilled methanol- $D I-\mathrm{H}_{2} \mathrm{O}(9: 1, \mathrm{v} / \mathrm{v})$ was used to coat the denuders according to EPA Compendium Method IO-4.2 (USEPA, 1999).

The collection efficiency of the denuders was evaluated by flowing $\left(10 \mathrm{~L} \mathrm{~min}^{-1}\right)$ a known concentration of the target analyte through two denuders for a given period of time $(0.5-2 \mathrm{~h})$. The denuders were rinsed with deionized water $\left(D I-\mathrm{H}_{2} \mathrm{O}, 2 \times 5 \mathrm{~mL}\right)$ and the aqueous extracts were analyzed using methods described here. Base-coated denuders were rinsed with $0.04 \mathrm{M}$ sodium hydroxide solution. Controls were carried out using coated denuders that were not exposed to the target analyte. Collection efficiency $(C E)$ is calculated from:

$$
C E=\frac{A_{1}}{\left(A_{1}+A_{2}\right)} \times 100 \%
$$

where $A_{1}$ and $A_{2}$ are the concentrations of the analyte collected in denuder 1 and 2, respectively.

\section{S.1.6 Impinger efficiency tests}

Amine and activated primary amine collection efficiency tests using impinger systems were conducted using an analogous approach to that described above and is shown schematically in Figure S1. In a typical one hour experiment, syringe pump SP (Model 55-1144, Harvard Apparatus, Holliston, MA) was used to infuse $\left(1.5 \mathrm{~mL} \mathrm{~h}^{-1}\right)$ an aqueous solution of diethylamine and aniline (ca. $20 \mathrm{mM}, 0.5 \mathrm{~mL}$ ) into a stream of nitrogen $\left(\mathrm{G}, 1.3 \mathrm{~L} \mathrm{~min}^{-1}\right.$ ) flowing through a heated $\left(205^{\circ} \mathrm{C}\right)$ stainless steel tee. Pump $\mathrm{P}$ aspired a gas sample $\left(0.8 \mathrm{~L} \mathrm{~min} \mathrm{~m}^{-1}\right)$ from the atmospheric vent through impingers I1 and I2. The pump and vent exhausts were vented to a fume hood. In analogous tests, an unheated miniature bubbler containing an alkaline ( $\mathrm{pH} 10)$, 
aqueous solution of methylamine hydrochloride $\left(40 \mathrm{mg} \mathrm{L}^{-1}, 0.59 \mathrm{mM}\right)$ was used in lieu of the syringe pump system. Similar procedures were used for $\mathrm{X}-\mathrm{NH}_{2}$ compounds, which were used as their hydrochloride or sulfate salts. For $\mathrm{NH}_{3}$, the heated tee and syringe pump were omitted and a blended $100 \mathrm{ppbv}$ gaseous $\mathrm{NH}_{3}$ stream was used. Aliquots from the impingers were derivatized and analyzed as described below.

The apparatus depicted in Figure S1A was adapted to measure collection efficiency in undiluted vehicle exhaust as shown in Figure S1B. The heated sampling probe consisted of $1 \mathrm{~m}$ Teflon tubing ( $6.4 \mathrm{~mm} \mathrm{OD})$ in a copper sheath, which was wrapped with a string heater, followed by insulation. The temperature of the probe was controlled at $80^{\circ} \mathrm{C}$. Approximately $20 \mathrm{~cm}$ of the heated probe (uninsulated) was inserted into the exhaust pipe with the vehicle running under equilibrated idling conditions. Undiluted vehicle exhaust spiked with the analytes of interest was aspired through the impinger train for 60-90 min, depending on the experiment, at $0.8 \mathrm{~L} \mathrm{~min}^{-1}$. Aliquots from the impingers were derivatized and analyzed as described below. 
Table S1. Comparison of Heat Block and Microwave Heating of the Reaction Medium in the DNFB Mediated Derivatization of Amines. Yields are calculated based on recovery of derivatized products relative to standards of authentic samples of known concentration. Note that yields exceeding $100 \%$ likely are due to solvent evaporation.

\begin{tabular}{|c|c|c|c|c|}
\hline \multirow[t]{2}{*}{ Amine } & \multicolumn{2}{|c|}{ Heat Block } & \multicolumn{2}{|c|}{ Microwave Irradiation } \\
\hline & Variability $(\%)^{\mathrm{a}}$ & Yield $(\%)^{b}$ & Variability $(\%)^{\mathrm{a}}$ & Yield $(\%)^{b}$ \\
\hline methylamine & 2.2 & 116 & 3.8 & 113 \\
\hline diethylamine & 1.1 & 79 & 1.8 & 82 \\
\hline aniline & 0.9 & 120 & 3.8 & 113 \\
\hline
\end{tabular}

acalculated as the standard deviation from four replicates divided by the mean

${ }^{b}$ mean of four replicates 
Table S2. Summary of Methods Evaluated for $\mathrm{X}-\mathrm{NH}_{2}$ Derivatization.

\# Method Summary

A Spike $\mathrm{H}_{3} \mathrm{PO}_{3} \operatorname{soln}(0.04 \% \mathrm{w} / \mathrm{v}, 3 \mathrm{~mL})$ with $\mathrm{H}_{2} \mathrm{NNH}_{2} \& \mathrm{H}_{2} \mathrm{NOH}$

Evaporate to dryness

Dissolve residue in 2-furaldehyde solution (0.5 $\mathrm{M}$ in $\mathrm{MeOH}, 1 \mathrm{~mL})$

Heat for $2 \mathrm{~h}$

B Spike $\mathrm{H}_{3} \mathrm{PO}_{3} \operatorname{soln}(0.04 \%$ w/v, $3 \mathrm{~mL})$ with $\mathrm{H}_{2} \mathrm{NNH}_{2} \& \mathrm{H}_{2} \mathrm{NOH}$

Evaporate to dryness

Dissolve residue in 2-furaldehyde solution (0.5 $\mathrm{M}$ in $\mathrm{MeOH}, 1 \mathrm{~mL})$

Heat for $2 \mathrm{~h}$

Evaporate to dryness

Suspend residue in $\mathrm{H}_{2} \mathrm{O}(1 \mathrm{~mL})$, extract with EtOAc $(1 \mathrm{~mL})$, \& dry over $\mathrm{Na}_{2} \mathrm{SO}_{4}$

C Spike 2-furaldehyde solution $(0.5 \mathrm{M}$ in $\mathrm{MeOH}, 1 \mathrm{~mL})$ with $\mathrm{H}_{2} \mathrm{NNH}_{2}$ \& $\mathrm{H}_{2} \mathrm{NOH}$

Heat for $2 \mathrm{~h}$

D Spike $\mathrm{H}_{3} \mathrm{PO}_{3} \operatorname{soln}(0.04 \%$ w/v, $3 \mathrm{~mL})$ with $\mathrm{H}_{2} \mathrm{NNH}_{2} \& \mathrm{H}_{2} \mathrm{NOH}$

Add 2-furaldehyde $(124 \mu \mathrm{L})$

Heat for $2 \mathrm{~h}$

Extract with EtOAc $(1 \mathrm{~mL}) \&$ dry over $\mathrm{Na}_{2} \mathrm{SO}_{4}$ 

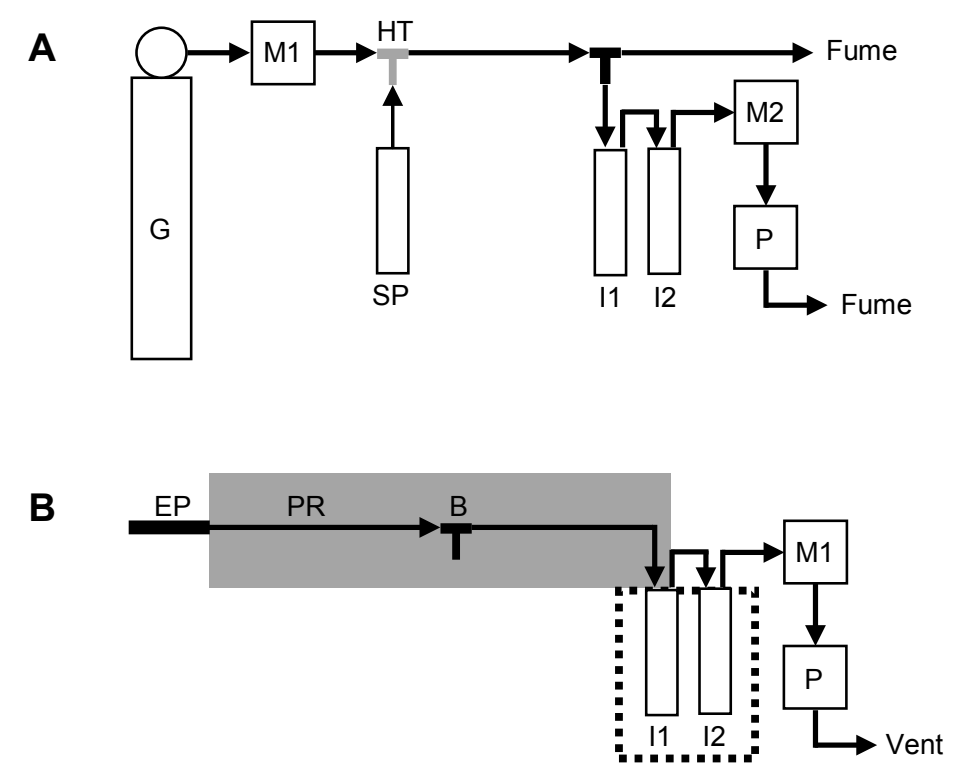

Figure S1. Schematic of the Impinger Systems for Efficiency Testing.

A. In an ambient air setting; G, gas supply; M1, M2, mass-flow controllers; HT, heated metal Tee connection; SP, syringe pump; I1, I2, impinger; P, pump.

B. With undiluted vehicle exhaust. EP, exhaust pipe; PR, heated sampling probe; HT, heated metal Tee connection; B, miniature bubbler; I1, I2, impinger; M1, mass-flow controller; P, pump. 


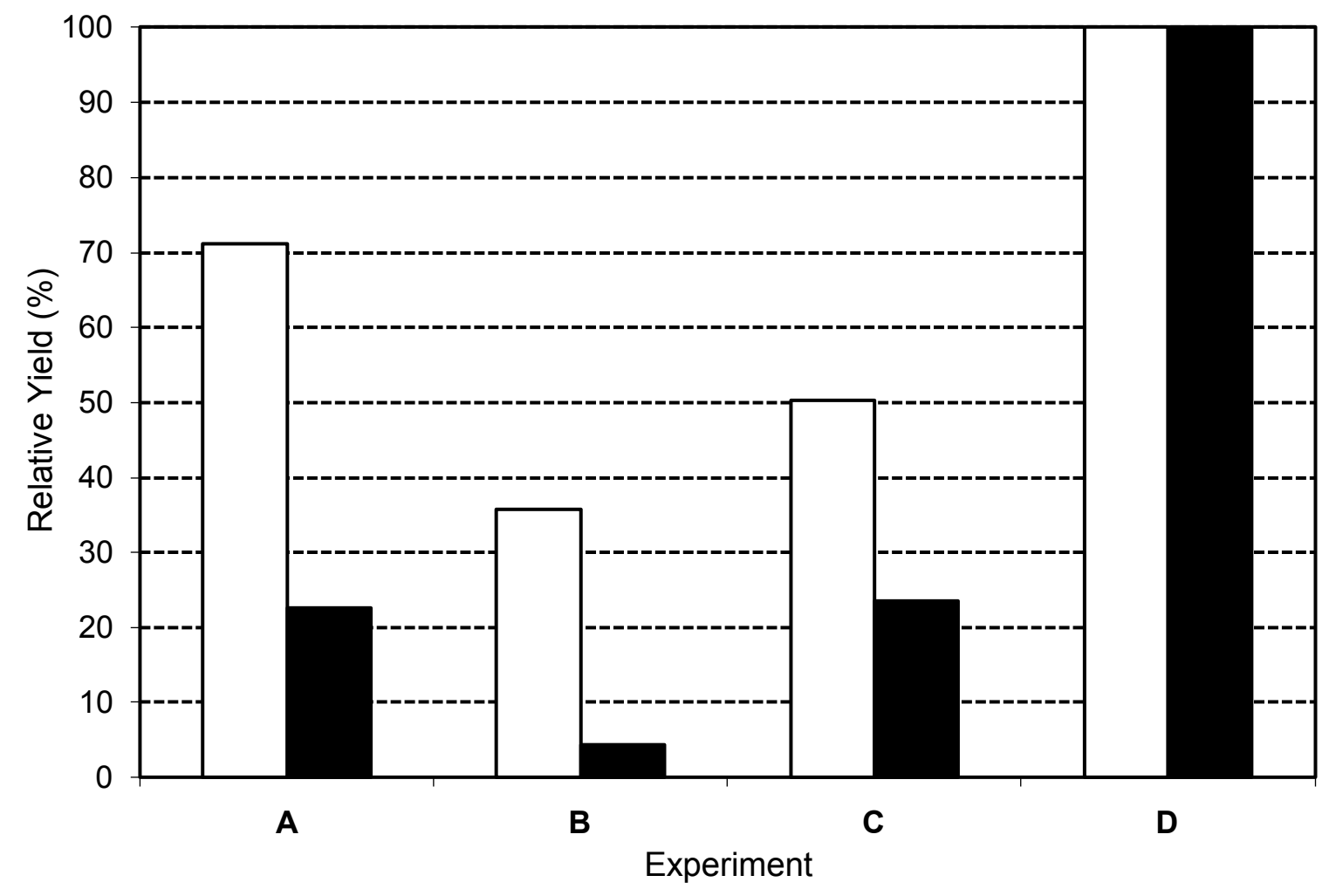

Figure S2. Yield (relative to maximum) of 2-Furaldehyde Azine (open) and 2-Furaldehyde Oxime (closed) as a Function of Reaction Conditions. 


\section{References}

Day, E. W., Golab, T., and Koons, J. R.: Determination of Micro Quantities of C1-C4 Primary and Secondary Amines by Electron Affinity Detection, Anal. Chem., 38, 1053-1057, 1966.

Elder, J. W., and Holtz, K. M.: Microwave Microscale Organic Experiments, J. Chem. Educ., 73, A104-A105, 1996.

Hollingsworth, B. L.: The Reaction of Nitrogen Dioxide with Some Methylnitroanilines, J. Chem. Soc., 2420-2425, 1959.

USEPA: Compendium Method IO-4.2 - Determination of Reactive Acidic and Basic Gases and Strong Acidity of Atmospheric Fine Particles $(<2.5 \mu \mathrm{m})$, United States Environmental Protection Agency, Office of Research \& Development, Research Triangle Park, NCEPA/625/R96/010a, 1999. 